\title{
An endophyte Paenibacillus dendritiformis strain APL3 promotes Amaranthus polygonoides L. sprout growth and their extract inhibits food-borne pathogens
}

\author{
Ramalingam Radhakrishnan ${ }^{1,2 *}$, Ajithkumar $\mathrm{P}^{2}$, Muthukrishnan Arun ${ }^{3}$, Ramaraj Sathasivam ${ }^{4}$, Sandhya \\ $\mathrm{S}^{2}$, Jaehyuk Choi ${ }^{5}$, Pradeep B V ${ }^{2}$ \& Sang Un Park ${ }^{4^{*}}$ \\ ${ }^{1}$ Department of Botany, Jamal Mohamed College (Autonomous), Affiliated to Bharathidasan University, Tiruchirappalli 620 020, India \\ ${ }^{2}$ Department of Microbiology, Karpagam Academy of Higher Education, Coimbatore, India \\ ${ }^{3}$ Department of Biotechnology, Bharathiar University, Coimbatore, India \\ ${ }^{4}$ Department of Crop Science, Chungnam National University, 99 Daehak-ro, Yuseong-gu, Daejeon 34134, Republic of Korea \\ ${ }^{5}$ Research Institute of Knowhere bio Inc., Seongnam, 13449, Republic of Korea \\ *Email: rkbot@jmc.edu /supark@cnu.ac.kr
}

\section{ARTICLE HISTORY}

Received: 13 May 2021

Accepted: 05 September 2021

Available online: 14 October 2021

\section{KEYWORDS}

Antimicrobial activity

Endophytes

Plant growth

Spinach extract

\section{ABSTRACT}

Green leafy vegetables are rich sources of antioxidants and minerals, which prevent food-borne pathogen infections during our diet. This study was aimed to isolate and identify the plant growthpromoting endophytic bacterium from several plant species to enhance the growth of Amaranthus polygonoides L. and their antimicrobial potential against food-borne pathogens. Seven endophytic bacterial isolates were tested on two Amaranthus species to identify the suitable beneficial bacterium. The antioxidants capacity and antimicrobial activity of bacterial isolate (APL3) treated plants were analyzed. The bacterial isolate, APL3 showed a significantly higher growth of A. polygonoides L. than other isolates. It was identified as Paenibacillus dendritiformis strain APL3 by 165 rRNA gene sequencing and phylogenetic analysis. The endophyte (APL3) treated A. polygonoides L. sprouts had higher antioxidants potentials and significantly inhibited the growth of Escherichia coli, Salmonella sp., Staphylococcus sp. and Pseudomonas sp. The results of the present study suggest that utilization of $P$. dendritiformis strain APL3 triggers the growth of A. polygonoides L. and induces metabolic changes in plants to improve their antimicrobial properties to prevent foodborne pathogens.

\section{Introduction}

The food contains a lot of nutrients and microorganisms, and those microorganisms are friends or foes to humans and other organisms (1) The consumption of raw vegetables, half-cooked food, and non-hygienic preparation of food may have the chance to generate diseases in consumers. The anthropogenic activities including sewage disposal to water bodies and improper maintenance of water tanks are the sources of water-borne diseases (2). Food-borne diseases are a major health issue worldwide and reduce national economies (3). The microbial contaminated food and drinking water cause several diseases including diarrhea, typhoid, cholera, salmonellosis and hepatitis A. Escherichia coli, Salmonella spp., Staphylococcus spp. and Pseudomonas are common food-borne pathogens that infect the human populations. The microbiological safety of foods is prime research in the current era. The physicians are suggesting antibiotic drugs to cure the disease. The misuse or overuse of those drugs will not be effective to control the pathogen growth due to antibiotic resistance (4). The antimicrobial potential of plant extracts would be an alternative to synthetic drugs to prevent diseases and defeat antibiotic resistance (5).

Several plants were identified to suppress the growth of food-borne microorganisms. Spinach (Amaranthus spp.), is a leafy vegetable contains a rich amount of antioxidants, vitamins and minerals (6) and control pathogen infections. Minerals are essential nutritional elements for living organisms to perform several biochemical reactions by activating enzymes (7). The enhancement of the nutritional value of spinach is one of the major areas of worldwide spinach researchers (8). Spinach cultivation is affected by diseases, insect infestation, soil and other climatic factors. The usage of plant growth-promoting microorganisms in sustainable agriculture is well established to enhance plant growth, nutritional

(C) Radhakrishnan et al (2021). This is an open-access article distributed under the terms of the Creative Commons Attribution License, which permits unrestricted use, distribution and reproduction in any medium, provided the original author and source are credited (https://creativecommons.org/licenses/by/4.0/). 
values, tolerate abiotic stresses and resistance to diseases (9-11). Plant growth-promoting bacteria trigger the growth and yield of crop plants. The plant growth promotion of endophytic bacteria has been an emerging study to improve the crop response against several environmental stresses. Recently, an endophytic bacterium Bacillus methylotrophicus KE2 isolated from Kimchi leaves showed plant growthpromoting activities in lettuce, a green leafy vegetable and also enhanced their food values (12). In addition, the association of endophytic bacteria with plants helps to obtain mutual benefits during adverse environmental conditions. Some of the drought, salt, heavy metal and biocontrol microorganisms were identified and successfully applied to plants to enhance resistance or tolerance against unfavorable conditions (13). The drought-tolerant and phosphate solubilizing microorganisms (Pseudomonas libanensis, Streptomyces laurentii, Acinetobacter calcoaceticus, and Penicillium sp.) enhance the plant growth under drought stress conditions $(14,15)$. The bacterial cellfree extracts containing the plant growth-promoting substances enhance the plant growth and increase the macro and micronutrients (16).

Amaranthus polygonoides $\mathrm{L}$. is a herbaceous medicinal plant containing antioxidants, which prevent cancer cell growth and inhibit the growth of disease-causing organisms such as Staphylococcus aureus, Staphylococcus epidermidis, Micrococcus luteus, Bacillus subtilis, Escherichia coli, Pseudomonas aeruginosa, Klebseilla pneumonia, Aspergillus niger and Aspergillus fumigatus (17). It is a common green leaves vegetable in southern India. In the present study, we used endophytic bacterium to enhance the growth, increase the antimicrobial and antioxidant properties of Amaranthus polygonoides L. The interaction of bacterium, Paenibacillus dendritiformis strain APL3 isolated from leaf tissues of Andrographis paniculata $\mathrm{L}$. was not reported in $A$. polygonoides $\mathrm{L}$. This study was aimed to promote the $A$. polygonoides L. sprout growth and medicinal values by endophytic bacterial treatment.

\section{Materials and Methods}

\section{Collection of plant samples}

The leaves or and flowers sample of Nerium oleander L., Hibiscus rosa-sinensis L., Plectranthus amboinicus L., Ocimum tenuiflorum L., Andrographis paniculata L., Catharanthus roseus L., Mentha arvensis L. and Centella asiatica L. were collected from the south zone of Coimbatore, Tamilnadu, India.

\section{Isolation of endophytic bacteria from different plant samples}

The selected plant samples were cleaned in running tap water to remove the dust particles and surface sterilized with $0.1 \%$ mercuric chloride for $5 \mathrm{~min}$ and $70 \%$ ethanol for $45 \mathrm{sec}$. The chemical deposition from the leaves or flowers was removed after washing with sterile distilled water. The leaves and flowers were separately sliced with a sterile knife and ground in mortar and pestle. The extract of plant materials was serially diluted and spread on the tryptic soy agar
(TSA) medium. The inoculated plates were kept at $35 \pm$ $2^{\circ} \mathrm{C}$. The different bacterial colonies were observed every day and numbers of bacterial colonies were recorded up to 10 days. The bacterial colonies were differentiated by their morphology, pigmentation and growth rate. The individual bacterial colonies were separated and the pure culture of each isolate was maintained in a nutrient agar medium.

\section{Screening of endophytic bacteria to promote plant growth}

Seeds of Amaranthus polygonoides L. and Amaranthus atropurpurea L. were surface sterilized with $0.1 \%$ mercuric chloride and $70 \%$ ethanol as per the method described above. The sterilized seeds were three times rinsed with sterile distilled water and transferred to the nutrient broth culture of each bacterial isolate. The seeds were allowed to co-culture with endophytic bacteria for three hours. The seeds were carefully shifted to petri-plates containing sterilized cotton and tissue paper. The sterile water was sprayed on plates to keep the moisture level. The height of seedlings was compared with control (without endophytes treated seedlings) to check the plant growth promotion activity of endophytes.

\section{Identification of endophytic bacterium}

The bacterial strain (APL3) was isolated from Catharanthus roseus L. leaves and inoculated on plates containing tryptic soy agar medium and incubated for $48 \mathrm{hr}$ at $35^{\circ} \mathrm{C}$. The biochemical analysis such as Gram staining, methyl red, Voges Proskauer, citrate utilization, oxidase, catalase, urease, ammonia production and motility test were conducted to identify the bacterium. The bacterial isolate, APL3 was identified based on the partial 16S ribosomal rRNA gene sequence. The 27F primer (50AGAGTTTGATC(AC)TGGCTCAG-30) and 1492R primer (50-CGG(CT)TACCTTGTTACGACTT-30) were used for PCR amplification of the 16S rRNA gene. The BLAST search program (http://www.ncbi.nlm.nih.gov/BLAST/) was used to find the nucleotide sequence homology of this bacterial isolate. The relatively similar nucleotide sequences were aligned by ClustalW and MEGA (version 5.0) software and the neighbor-joining tree was generated. Bootstrap replication (1000 replications) was used to statistical support for the nodes in the phylogenetic tree.

\section{Antimicrobial activity of endophytes treated plants against food-borne pathogens}

The endophytes treated and non-treated sprouts of $A$. polygonoids L. were tried at $40{ }^{\circ} \mathrm{C}$ and ground to make powder. The crushed powder was dissolved in $10 \%$ dimethyl sulphoxide (DMSO) and applied to well in $E$. coli, Salmonella, Staphylococcus and Pseudomonas culture plates. The inhibition of microbial growth was visualized as clear zone formation and recorded by millimeters. The minimum inhibitory concentration was tested with gradients of plant extracts containing DMSO to identify the sub-lethal concentration.

\section{DPPH activity of sprouts}

The dried and powdered sprouts were mixed with methanol and DPPH scavenging activity was determined as per Blois (18) method. The methanol 
extract was allowed to react with diphenyl-1picrylhydrozol (DPPH) for $30 \mathrm{~min}$ in dark conditions. Hence, the absorbance of the reaction mixture was determined at $517 \mathrm{~nm}$. DPPH scavenging activity (\%) was calculated as follows:

DPPH scavenged $(\%)=($ A con $-A$ test $) / A$ con $\times 100$

A con-the absorbance of the control reaction; A testthe absorbance in the presence of the sample of the extracts.

\section{Statistical analysis}

The growth of sprouts treated with endophytes and other analyses were compared with their controls by statistical software, SPSS 11. The calculation of mean \pm SE (standard error) and one-way analysis of variance (ANOVA) of each sample were used to find out the significant difference between control and treatment.

\section{Results and Discussion}

Plant growth-promoting bacteria alter the physiological changes in plants to enhance plant growth (19). Endophytic bacteria present in plants significantly change the growth pattern and metabolites of host plants. The number of bacteria and fungi isolated from roots, stems, leaves, flowers, fruits and seeds expressed beneficial effects on plant growth and yield $(20,21)$. Forty-three bacterial isolates were obtained from Nerium oleander L., Hibiscus rosasinensis L., Plectranthus amboinicus L., Ocimum tenuiflorum L., Andrographis paniculata L., Catharanthus roseus L., Mentha arvensis L. and Centella asiatica L. plant tissues in this study (Table 1). The leaves of Andrographis paniculata L., Catharanthus roseus L., the root of Mentha arvensis L. and the stem of Centella asiatica L. had four numbers of different bacterial species. Leaf of Mentha arvensis L. had less number (one) of an endophytic bacterium. regulates nutritional and water uptake and balance in plants, stomatal conductance, osmolytes accumulation, photosynthesis, hormones, toxic substances and antioxidants to enhance the stressaffected plant growth $(25,26)$.

In addition, the plant growth promotion activity of endophytic bacterial isolates in two spinach species such as $A$. polygonoides L. and $A$. atropurpurea L. was observed in this study. The obtained results were recorded in Table 2. Bacterial isolates, APL3, CL3, CR1 and CL showed the best positive response in seedling development of two spinach species than others (Fig. 1). A. polygonoides L. growth was significantly higher due to the interaction of APL3 isolate. It was identified as Paenibacillus dendritiformis strain APL3 by $16 \mathrm{~S}$ rRNA sequencing

Table 2. Plant growth-promoting ability of endophytic bacteria in two spinach species

\begin{tabular}{cccc}
\hline Sl. No & $\begin{array}{c}\text { Bacterial } \\
\text { isolates }\end{array}$ & $\begin{array}{c}\text { Amaranthus } \\
\text { polygonoides L. }\end{array}$ & $\begin{array}{c}\text { Amaranthus } \\
\text { atropurpurea L. }\end{array}$ \\
\hline 1 & NOF1 & - & +++ \\
\hline 2 & APL3 & ++++ & - \\
\hline 3 & MAR1 & - & +++ \\
\hline 4 & MAL1 & - & ++ \\
\hline 5 & CAL3 & ++ & - \\
\hline 6 & CRR1 & +++ & - \\
\hline 7 & CRL3 & ++ & + \\
\hline
\end{tabular}

and phylogenetic analysis (Fig. 2). APL3 bacterial inoculation effectively promoted the shoot length of $A$. polygonoides L. (Fig. 3).

Some of the species of Paenibacillus produce several enzymes and acids to degrade the biological materials. For instance, the $P$. polymyxa CR1 genome contains endoglucanases, cellodextrinases, xylanases, mannanases, arabinofuranosidase, DyP-peroxidase and laccase genes, which are involving in solubilization of the biological macromolecules (27).

Table 1. Endophytic bacteria isolated from different plant samples

\begin{tabular}{|c|c|c|c|}
\hline Sl. No & Plant & Plant part & Total number of Bacterial isolates \\
\hline 1. & Nerium oleander L. & Flower & NOF1, NOF2 \\
\hline 2. & Nerium oleander L. & Leaf & NOL1,NOL2,NL3 \\
\hline 3. & Hibiscus rosa-sinensis $\mathrm{L}$. & Flower & HRF1,HRF2,HRF3 \\
\hline 5. & Ocimum tenuiflorum L. & Flower & OTF1,OTF2,OTF3 \\
\hline 6. & Ocimum tenuiflorum L. & Leaf & OTL1,OTL2,OTL3 \\
\hline 7. & Andrographis paniculata L. & Root & APR1,APR2,APR3 \\
\hline 9. & Catharanthus roseus L. & Root & CRR1,CRR2 \\
\hline 10. & Catharanthus roseus L. & Leaf & CRL1,CRL2,CRL3,CRL4 \\
\hline 11. & Mentha arvensis L. & Root & MAR1,MAR2,MAR3,MAR4 \\
\hline 12. & Mentha arvensis L. & Leaf & MAL1 \\
\hline 13. & Centella asiatica $\mathrm{L}$. & Leaf & CAL1,CAL2,CAL3 \\
\hline 14. & Centella asiatica L. & Root & CAR1,CAR2,CAR3 \\
\hline 15. & Centella asiatica $\mathrm{L}$. & Stem & CAS1,CAS2,CAS3,CAS4 \\
\hline
\end{tabular}

The diversity of endophytes present inside the plant tissues was determined by tissues, developmental stage, and plant species $(22,23)$. The association of endophytes and their composition influences the growth of host plants and stimulates the production of valuable compounds (24). Endophytic bacterial interaction supports plant growth against various environmental stresses including soil salinity. It
The glucose degradation (methyl red test), oxidase, catalase, urease and ammonia production characters of APL3 might be a reason for enhancing $A$. polygonoides L. growth. The antioxidants enzymes like oxidase and catalase reduce the oxidative stress in plants (10) and the synthesis of those enzymes in plants by bacteria would be a favor for plant growth improvement. Nitrogen is a major essential nutrient 

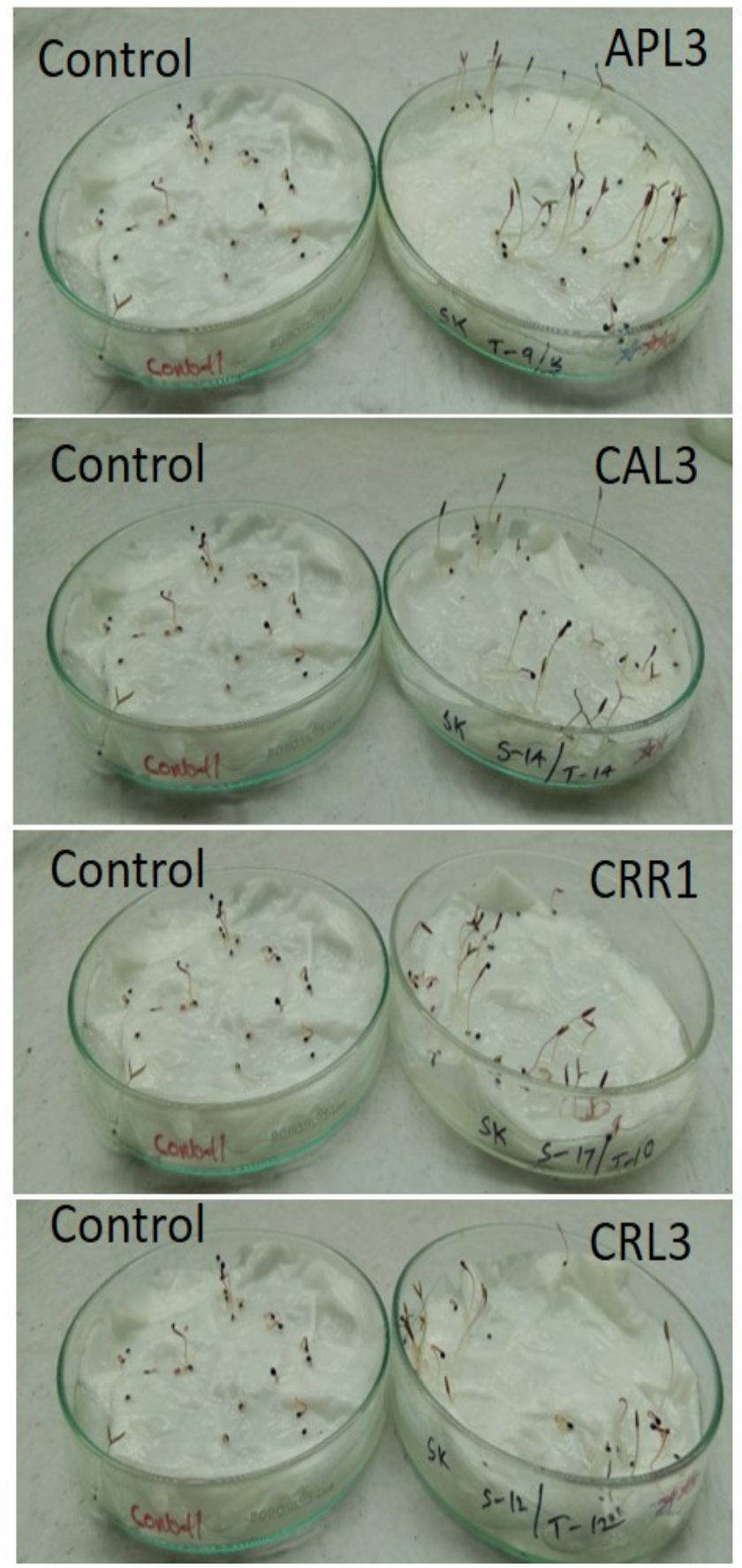

Fig. 1. Effect of endophytic bacteria on A. polygonoides L. seedling growth.

required for plant cell development. The urease and ammonia production ability of APL3 stimulated the nitrogen accumulation in plants to promote their growth and health. Recently, it was reported that $P$. polymyxa promoted the growth of maize, cucumber and potato plants by the utilization of atmospheric nitrogen (28). In addition, Paenibacillus sps. produce indole 3 acetic acid in Curcuma longa L. (29).

The bioactive compounds present in the plants can act as antimicrobial drugs to prevent the infection of several foodborne pathogens (30). The common human pathogens including Escherichia coli, Salmonella, Staphylococcus aureus and Pseudomonaus aeruginosa infections are prevented by several herbal treatments. The edible green leafy vegetables of

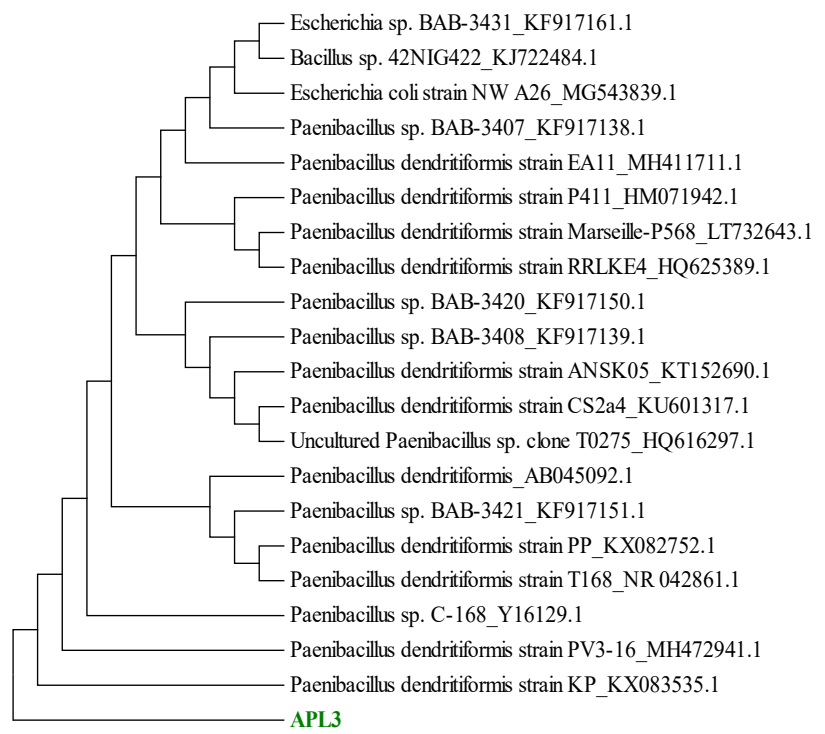

Fig. 2. Phylogenetic tree based on the sequence obtained from $27 \mathrm{~F}$ and 1492R primers of 16S rRNA gene of endophytic bacteria (APL3) and those of related bacteria.

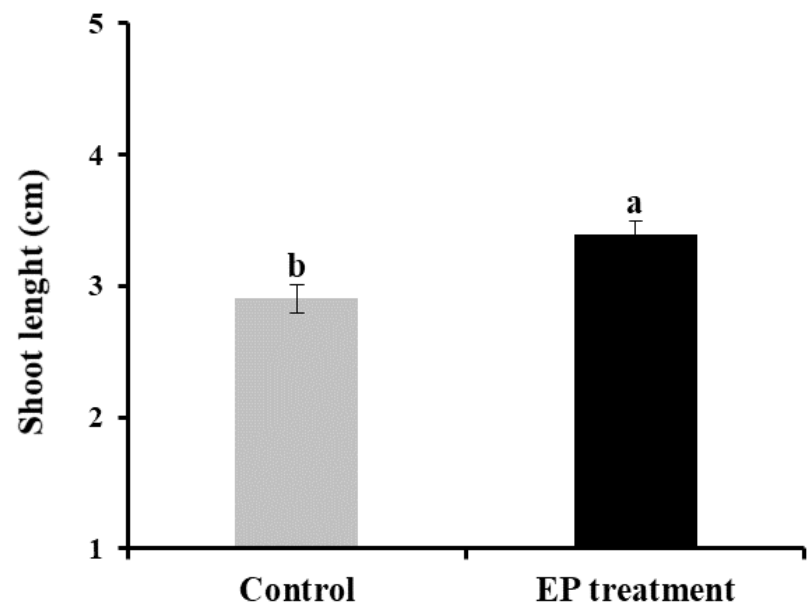

Fig. 3. Influence of $P$. dendritiformis strain APL3 on shoot length of A. polygonoides L. seedlings.

Amaranthus species contain antimicrobial compounds which were inhibited $E$. coli, $S$. aureus and $P$. aeruginosa growth (17). In the present study, results revealed that APL3 treated plant extract produced higher antimicrobial activity against $E$. coli, S. aureus and $P$. aeruginosa than control plants (Fig. 4). The different concentrations of the plant extract from $50 \mu \mathrm{l}$ to $100 \mu \mathrm{l}$ showed a similar pattern of antimicrobial response against the pathogens, which was confirmed the endophytic bacterial (APL3) treatment can able to promote the antimicrobial contents of the plants. It was suggested that endophytes had a wide range of metabolites which is act as antimicrobial agents (31). The medicinally valuable antimicrobial compounds such as polymyxins and fusaricidins derived from the Paenibacillus sp. are useful to cure several diseases $(32,33)$. In addition, the presence of antioxidants was detected and quantified in both control and endophytes treated plants (Fig. 5). The antioxidants activity of $A$. polygonoides leaves was recorded (17). The significantly higher rate of antioxidant activity 

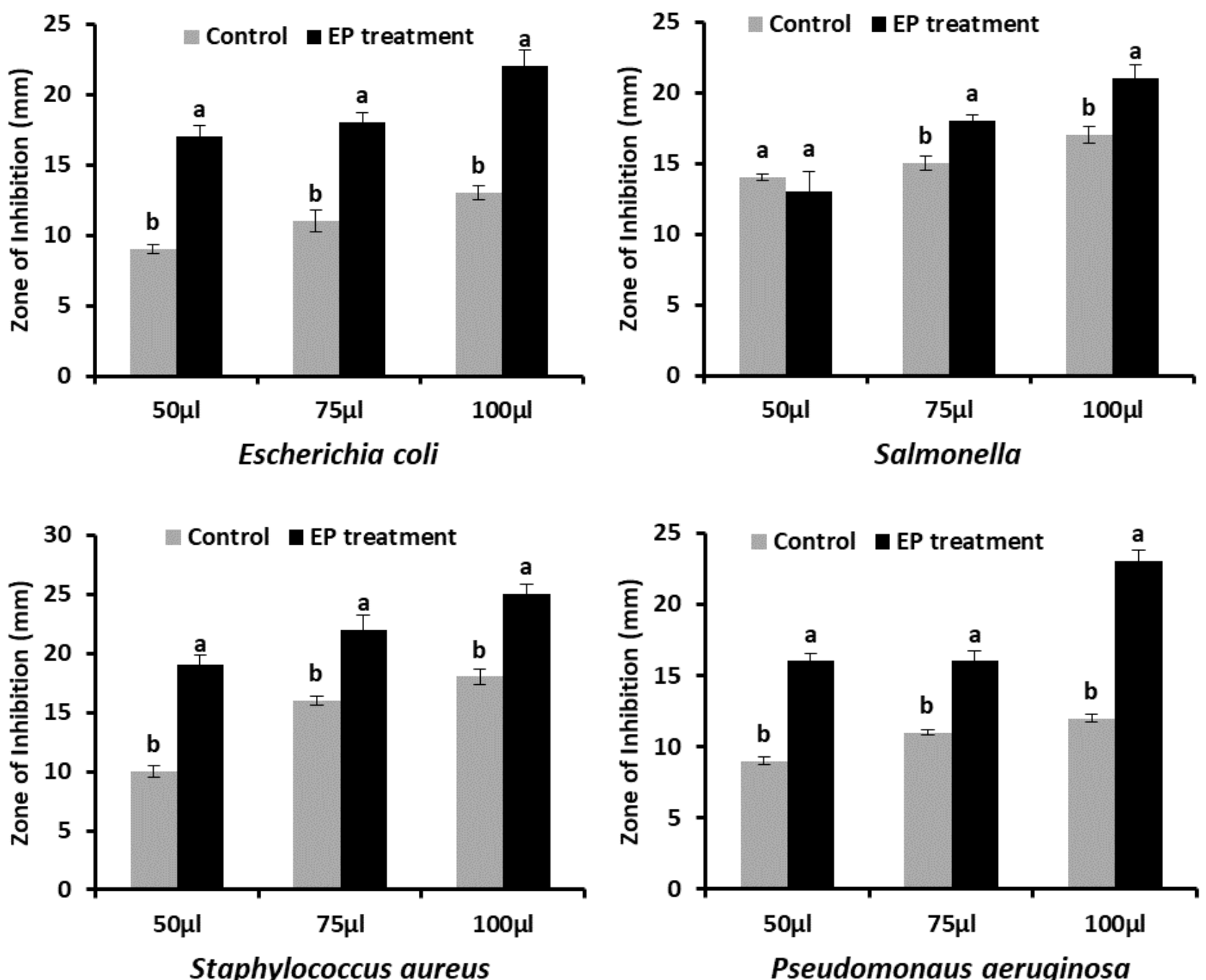

Fig. 4. Antimicrobial activity of $P$. dendritiformis strain APL3 associated A. polygonoides L. against food-borne pathogens.

was noticed in plants treated with APL3 while compared to their control, and the application of bacterial culture to plants enhanced the plant growth and their antioxidants activity would be useful for human consumption.

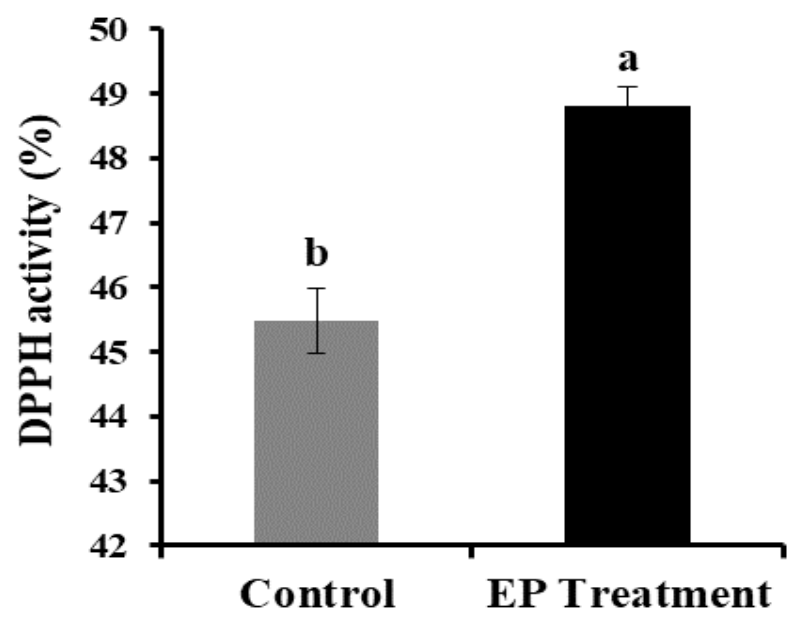

Fig. 5. Effect of $P$. dendritiformis strain APL3 on antioxidant capacity (DPPH activity) of $A$. polygonoides L.

\section{Conclusion}

The results of the present study suggest that utilization of $P$. dendritiformis strain APL3 triggers the growth of $A$. polygonoides L. and induces the metabolic changes in plants to improve their antimicrobial properties to reduce the growth of foodborne pathogens. Further study will be focused on the isolation of antimicrobial compounds from endophytes treated plants to know the mode of action for controlling foodborne pathogens.

\section{Acknowledgements}

The authors thank Jamal Mohamed College (Autonomous), Tiruchirappalli, India and Karpagam Academy of Higher Education, Coimbatore, India for encouraging research through seed money projects. The authors thank the Department of Biotechnology (DBT), Department of Science and Technology (DST) under the Government of India for providing facilities to carry out the research. 


\section{Authors' contributions}

RR and SUP conceived the study. AP, MA, RS, SS, JC, and PBV. performed the experiments and analyzed the data. SR performed computational analysis. RR, RS, and SUP. Writing - review and editing. All of the authors read and approved the final manuscript.

\section{Compliance with ethical standards}

Conflict of interest: The authors do not have any conflict of interest to declare.

Ethical issues: None.

\section{References}

1. Josephs-Spaulding J, Beeler E, Singh OV. Human microbiome versus food-borne pathogens: friend or foe. Appl Microbiol Biot. 2016;100(11):4845-63. https://doi.org/10.1007/s00253-016-7523-7

2. Radhakrishnan R, Dharmaraj K, Kumari BR. A comparative study on the physicochemical and bacterial analysis of drinking, borewell and sewage water in the three different places of Sivakasi. J Environ Biol. 2007; 28(1):105-08.

3. Newell DG, Koopmans M, Verhoef L, Duizer E, Aidara-Kane A Sprong H, Opsteegh M, Langelaar M, Threfall J, Scheutz F, van der Giessen J, Kruse H. Food-borne diseases - The challenges of 20 years ago still persist while new ones continue to emerge. Int J Food Microbiol. 2010;139:S3-S15. https://doi.org/10.1016/j.ijfoodmicro.2010.01.021

4. Michael CA, Dominey-Howes D, Labbate M. The antimicrobial resistance crisis: causes, consequences and management. Front Public Health. 2014;2:145. https://doi.org/10.3389/ fpubh.2014.00145

5. Cirmi S, Bisignano C, Mandalari G, Navarra M. Anti-infective potential of Citrus bergamia Risso et Poiteau (bergamot) derivatives: a systematic review. Phytother Res. 2016;30(9):1404-11. https://doi.org/10.1002/ptr.5646

6. Prasad SM, Parihar P, Singh VP. Effect of salt stress on nutritional value of vegetables. Biochem Pharmacol. 2014;3(2):e160. https://doi.org/10.4172/2167-0501.1000e160

7. Prashanth L, Kattapagari KK, Chitturi RT, Baddam VRR, Prasad LK. A review on role of essential trace elements in health and disease. J NTR Univ Health Sci. 2015;4(2):75.

8. Qin J, Shi AN, Mou BQ, Grusak MA, Weng YJ, Ravelombola W, Bhattarai G, Dong LD, Yang W. Genetic diversity and association mapping of mineral element concentrations in spinach leaves. BMC Genomics. 2017;18:941. https://doi.org/10.1186/s12864-0174297-y

9. Kang SM, Radhakrishnan R, Lee IJ. Bacillus amyloliquefaciens subsp. plantarum GR53, a potent biocontrol agent resists Rhizoctonia disease on Chinese cabbage through hormonal and antioxidants regulation. World J Microb Biot. 2015;31(10):1517-27. https://doi.org/10.1007/s11274-015-1896-0

10. Radhakrishnan R, Lee IJ. Penicillium-sesame interactions: A remedy for mitigating high salinity stress effects on primary and defense metabolites in plants. Environ Exp Bot. 2015;116:47-60. https://doi.org/10.1016/j.envexpbot.2015.03.008

11. Radhakrishnan R, Lee IJ. Foliar treatment of Bacillus methylotrophicus KE2 reprograms endogenous functional chemicals in sesame to improve plant health. Indian J Microbiol. 2017;57(4):409-15. https://doi.org/10.1007/s12088-017-0666-0

12. Radhakrishnan R, Lee IJ. Gibberellins producing Bacillus methylotrophicus KE2 supports plant growth and enhances nutritional metabolites and food values of lettuce. Plant Physiol Bioch. 2016;109:181-89. https://doi.org/10.1016/ j.plaphy.2016.09.018

13. Radhakrishnan R, Hashem A, Abd Allah EF. Bacillus: A biological tool for crop improvement through bio-molecular changes in adverse environments. Front Physiol. 2017;8:667. https:// doi.org/10.3389/fphys.2017.00667
14. Kour D, Rana KL, Kaur T, Sheikh I, Yadav AN, Kumar V, Dhaliwal HS, Saxena AK. Microbe-mediated alleviation of drought stress and acquisition of phosphorus in great millet (Sorghum bicolor L.) by drought-adaptive and phosphorus-solubilizing microbes. Biocatal Agric Biotechnol. 2020;23:101501. https:// doi.org/10.1016/j.bcab.2020.101501

15. Kour D, Rana KL, Sheikh I, Kumar V, Yadav AN, Dhaliwal HS, Saxena AK. Alleviation of drought stress and plant growth promotion by Pseudomonas libanensis EU-LWNA-33, a drought-adaptive phosphorus-solubilizing bacterium. Proc Natl Acad Sci India Sect. B Biol Sci. 2019;785-95. https://doi.org/10.1007/ s40011-019-01151-4

16. Lee K-E, Radhakrishnan R, Kang S-M, You Y-H, Joo G-J, Lee I-J, Ko, J-H, Kim J-H. Enterococcus faecium LKE12 cell-free extract accelerates host plant growth via gibberellin and indole-3-acetic acid secretion. J Microbiol Biotechnol. 2015;25(9):1467-75. https://doi.org/10.4014/jmb.1502.02011

17. Naveena B, Narayani TG, Sakthiselvan P, Partha N. Antioxidant and antimicrobial efficacies of Amaranthus polygonoides and its impact on L-asparaginase production. Afr J Biotechnol. 2012;11(61):12483-90. https://doi.org/10.5897/AJB12.098

18. Blois MS. Antioxidant determinations by the use of a stable free radical. Nature. 1958;181:1199-1200. https://doi.org/ 10.1038/1811199a0

19. Jabborova D, Enakiev Y, Sulaymanov K, Kadirova D, Ali A, Annapurna K. Plant growth promoting bacteria Bacillus subtilis promote growth and physiological parameters of Zingiber officinale Roscoe. Plant Sci Today. 2021;8(1):66-71. https://doi.org/ 10.14719/pst.2021.8.1.997

20. Kang SM, Radhakrishnan R, Khan AL, Kim MJ, Park JM, Kim BR, Shin DH, Lee IJ. Gibberellin secreting rhizobacterium, Pseudomonas putida H-2-3 modulates the hormonal and stress physiology of soybean to improve the plant growth under saline and drought conditions. Plant Physiol Bioch. 2014;84:115-24. https://doi.org/10.1016/j.plaphy.2014.09.001

21. Kang SM, Radhakrishnan R, You YH, Joo GJ, Lee IJ, Lee KE, Kim JH. Phosphate solubilizing Bacillus megaterium mj1212 regulates endogenous plant carbohydrates and amino acids contents to promote mustard plant growth. Indian J Microbiol. 2014B;54(4):427-33. https://doi.org/10.1007/s12088-014-0476-6

22. Hassan SE. Plant growth-promotin.g activities for bacterial and fungal endophytes isolated from medicinal plant of Teucrium polium L. J Adv Res. 2017;8(6):687-95. https://doi.org/10.1016/j.jare.2017.09.001

23. van Overbeek L, van Elsas JD. Effects of plant genotype and growth stage on the structure of bacterial communities associated with potato (Solanum tuberosum L.). FEMS Microbiol Ecol. 2008;64(2):283-96. https://doi.org/10.1111/j.1574-6941.2008.00469.x

24. Dong LL, Cheng RY, Xiao LN, Wei FG, Wei GF, Xu J, Wang Y, Guo XT, Chen ZJ, Chen SL. Diversity and composition of bacterial endophytes among plant parts of Panax notoginseng. Chin MedUK. 2018;13:41. https://doi.org/10.1186/s13020-018-0198-5

25. Radhakrishnan R, Baek KH. Physiological and biochemical perspectives of non-salt tolerant plants during bacterial interaction against soil salinity. Plant Physiol Bioch. 2017;116:116-26. https://doi.org/10.1016/j.plaphy.2017.05.009

26. Vaishnav A, Shukla AK, Sharma A, Kumar R, Choudhary DK. Endophytic bacteria in plant salt stress tolerance: Current and future prospects. J Plant Growth Regul. 2019;38(2):650-68. https:// doi.org/10.1007/s00344-018-9880-1

27. Eastman AW, Heinrichs DE, Yuan ZC. Comparative and genetic analysis of the four sequenced Paenibacillus polymyxa genomes reveals a diverse metabolism and conservation of genes relevant to plant-growth promotion and competitiveness. BMC Genomics. 2014;15:851. https://doi.org/10.1186/1471-2164-15-851

28. Weselowski B, Nathoo N, Eastman AW, MacDonald J, Yuan ZC. Isolation, identification and characterization of Paenibacillus polymyxa CR1 with potentials for biopesticide, biofertilization, biomass degradation and biofuel production. BMC Microbiol. 2016;16:244. https://doi.org/10.1186/s12866-016-0860-y

29. Aswathy AJ, Jasim B, Jyothis M, Radhakrishnan EK. Identification of two strains of Paenibacillus sp. as indole 3 acetic acidproducing rhizome-associated endophytic bacteria from 
Curcuma longa. 3 Biotech. 2013;3(3):219-24. https:// doi.org/10.1007/s13205-012-0086-0

30. Vijaya Anand A, Velayuthaprabhu S, Rengarajan RL, Sampathkumar P, Radhakrishnan R. 2020. Bioactive compounds of guava (Psidium guajava L.). In: Murthy $\mathrm{H}$, Bapat V. (eds) Bioactive compounds in underutilized fruits and nuts. Refeernce Series in Phytochemistry, Springer, Cham, pp. 503-27.

31. Talukdar R, Tayung K. Endophytic fungal assemblages of Zanthoxylum oxyphyllum Edgew. and their antimicrobial potential. Plant Science Today 2021;8(1):132-139.

32. Grady EN, MacDonald J, Liu L, Richman A, Yuan ZC. Current knowledge and perspectives of Paenibacillus: a review. Microb Cell Fact. 2016;15:203. https://doi.org/10.1186/s12934-016-0603-7

33. Kajimura Y, Kaneda M. Fusaricidin A, a new depsipeptide antibiotic produced by Bacillus polymyxa KT-8 - Taxonomy, fermentation, isolation, structure elucidation and biological activity. J Antibiot. 1996;49(2):129-35.

https://doi.org/10.7164/
Additional information

Peer review information: Plant Science Today thanks Sectional Editor and the other anonymous reviewers for their contribution to the peer review of this work.

Reprints and permissions information is available

https://horizonepublishing.com/journals/index.php/PST/open_access_policy

Publisher's Note: Horizon e-Publishing Group remains neutral with regard to jurisdictional claims in published maps and institutional affiliations.

To cite this article: Radhakrishnan R, Ajithkumar P, Arun M, Sathasivam R, Sandhya S, Choi J, Pradeep B V, Park S U. An endophyte Paenibacillus dendritiformis strain APL3 promotes Amaranthus polygonoides L. sprout growth and their extract inhibits food-borne pathogens. Plant Science Today. 2021;8(4):941-947. https://doi.org/10.14719/pst.2021.8.4.1259

Plant Science Today, published by Horizon e-Publishing Group, is covered by Scopus, Web of Science, BIOSIS Previews, Clarivate Analytics, etc. See https://horizonepublishing.com/journals/index.php/PST/indexing_abstracting

antibiotics.49.129 